\title{
The Impact of Demographical Factors on Investment Decision: A Study of Vietnam Stock Market
}

\author{
Hoang Thanh Hue Ton ${ }^{1,2} \&$ Thi Minh Phuong Nguyen ${ }^{3}$ \\ ${ }^{1}$ School of Management, Shanghai University, Shanghai 200444, China \\ ${ }^{2}$ School of Economics and Business Management, Hong Duc University, Thanh Hoa City, Viet Nam \\ ${ }^{3}$ School of Economics, Vinh University, Vinh City, Viet Nam \\ Correspondence: Hoang Thanh Hue Ton, School of Management, Shanghai University, Shanghai 200444, China. \\ Tel: 86-21-1592-1373-032. E-mail: ththue14@gmail.com
}

Received: August 13, 2014

Accepted: September 17, 2014

Online Published: October 25, 2014

doi:10.5539/ijef.v6n11p83

URL: http://dx.doi.org/10.5539/ijef.v6n11p83

\begin{abstract}
Apart from the market situation, the investment decisions on stock markets base on the mentality of investors at the decision-making time. Each group of people with common characteristics may have the same or different thingking.This study aims to find out whether there is the discrepancy among classified groups of investors or not (the discrepancy in the risk taking investment decisions between male and female, in same age group, education, investment experience, income and marital status) Using Chi-square test, it is illustrated that male have more willingness to take risks in making investment decision than female; the elderly or retirement investors make the options of not taking risk; the investors with five-year-or-more investment experience often take higher risks than the others; the investors of different income levels have the same ability to take risk; the single investors show a tendency to take higher risks than maried investors.
\end{abstract}

Keywords: stock market, mentality, risk, investment decision and demographical factors

\section{Introduction}

Vietnam stock market was established in 2000, however, its booming time was in 2007 which pointed the landmark with the VNINDEX reaching 1170.6 points on 12nd March 2007, and then it continuously showed a decreasing trend and the lowest VNINDEX of 236 points on 24th February 2009. The security index has recently fluctuated around 500 points.

The growth of security index is one of indices showing the development of enterpries in particular and the whole economy in general. Each investor participating into the market plays an important role in this development, investment decisions have been made on the market signs, objective specific characteristics which influence the investor's mentality.Investors participate into the market to maximize the return based on the effective market theory (Fama, 1970). Besides maximized return expectation, Kahnenman\&Tversky took into consideration of psychological factors, emotion and risk which also influence on the investor's decision making (totally having a counter idea to Fama's theory) called the behavioural finance theory (Kahneman \& Tversky, 1979).

Apart from the bahavioural finance theory, the herd psychology (Barber, Odean, \& Zhu, 2009); over confidence(Shiller, 2000; Glaser \& Weber, 2007); excessive optimism (Gervais, Heaton, \& Odean, 2002); as well as risk-avoiding psychology (Shefrin \& Statman, 1985) also impact on the investor's decision. Besides the market information, price expectation, demographical factors influence significantly on the investor's decision.There have been a number of studies on the association of demographical factors and investment decisions, namely the different decisions between male and female (Bajtelsmit \& Bernasek, 1996); Gender and over confidence (Barber \& Odean, 2001); Gender, marital status, age, living area, income, career and professional qualification (Jain \& Mandot, 2012).

Different genders have psychological difference in making investment decisions, female are often more conservative than male (Bajtelsmit \& Van Derhei, 1996; Hinz, McCarthy, \& Turner, 1996). And female are not keen on making risky investment decisions (Bajtelsmi, Jianakoplos, \& Bernasek, 1996). Female often make safe decisions rather than run risks even when they are given reasonable advice or they think that they can get higher return if they take risks. Besides, male often trade much more than female (Barber \& Odean, 2001). 
There are a number of studies in demographical factors taken up in many countries and their findings are different due to the characteristics of each stock market.For instance, Jain and Mandot concluded that gender had no effect on the investor's decision while Bajtelsmit and Van Derhei; Hinz, McCarthy and Turner discovered that women always make a more cautiuos decision than men do because of the risk-avoiding psychology.

Another study taken up by Jain \&Mandot in Rajasthan stock market in India shows that out of demographical factors, age, marital status, income and educational qualification, professional qualification impact on stock investment decision, gender and living area have no effect on the investor's decision (Jain \& Mandot, 2012).

There are some studies in behavioural finance on Vietnam Stock Market. Particularly, (Nguyen, 2012) found out the association of macroeconomic factors and investors' bahaviour and (Le, 2009) brought out the bahavioural theory on Vietnam staock market. However, these studies only focuses on theory and no one has studied the influence of demographical factors on the investors' decision. Therefore, this study finds out the impact of demographical factors on the investors' decision.

\section{Methodology}

\subsection{Study Design}

The study has been designed based on the interviews of investors on Vietnam Stock Market in August and September 2013. The questionnaire has been designed in order to evaluate the impact of demographical factors on the investors' decision (the willingness to take risks). The demographical factors include gender, age, stock investment experience, educational qualification, income level, marital status.

\subsection{The Object of Study}

The objects of study consist of investors on Hanoi and Ho Chi Minh Stock Exchage of Vietnam Stock Market. The studied objects are both male and female at different ages, because the objective diversity makes the study much more significant for each object.

\subsection{The Method to Analyse the Data}

The study aims to find out the association of demographical factors and investment decisions due to the fact that demographical factors are inner factors impacting on the investors' decision. All studied variables are norminal and ordinal, therefore, Chi-square test will be used to analyze the difference and the influence of variables on investors' decision (Aczel, 2008; Kenney \& Keeping, 1951).

Chi-square test is used to test the following hypothesis:

Ho: two variables are independent.

H1: two variables are dependent.

Apart from Chi-square test, some other methods are used to evaluate the association of two studied variables, such as Cramer V, Cofficient of contigency or Lambda. The hypothesises of these three methods are similar to the hypothesis of Chi-square test.

If P-value of the test is larger than 0.05 (the significant level of 5\%), the Ho hypothesis will be accepted. In case $\mathrm{P}$-value of the test is equal to or smaller than 0.05 , two studied variables are dependent on each other.

\section{Results}

3.1 Inspecting the Relationship between Gender and Taking Risks in Making Investment Decisions

Table 1. Chi-square test results for gender

\begin{tabular}{lll}
\hline & Value & p-value \\
\hline Pearson Chi-Square & $12.492^{\mathrm{a}}$ & .000 \\
Cramer's V & .172 & .000 \\
Contingency Coefficient & .170 & .000 \\
\hline
\end{tabular}

Note. The results are Drawn by SPSS.

Because P-values of Chi-square test, Cramer's V and Contingency Coefficientare equal to 0.00 less than 0.05, there is some differences in the willingness to take risks of male and female. In order to compare the willingness level to take risks of male and female, the author uses the bidirectional frequency table to conclude that male is proned to take higher risks than female in making investment decisions (Table 2). 
Table 2. The bidirectional frequency statistic table for gender

\begin{tabular}{lllll}
\hline & & Gender & & Total \\
& & Male & Female & \\
\hline \multirow{2}{*}{ Risk } & unwilling to take risks & 80 & 122 & 202 \\
\multirow{2}{*}{ Total } & willing to take risks & 125 & 95 & 220 \\
\hline
\end{tabular}

Note. The results are drawn by SPSS.

\subsection{Inspecting the Relationship between Age and Taking Risks in Making Investment Decisions}

Table 3. Chi-square test results for age

\begin{tabular}{lcc}
\hline & Value & p-value \\
\hline Pearson Chi-Square & $66.822 \mathrm{a}$ & .000 \\
Cramer's V & .398 & .000 \\
Contingency Coefficient & .370 & .000 \\
\hline
\end{tabular}

Because P-values of Chi-square test, Cramer's V and Contingency Coefficient are less than 0.05, there is difference in the willingness to take risks of different age groups. I order to investigate the decision making of different age groups, the author devided the investors into different age groups as follows: the group of less than 27 years old; the group of from 27 to 35 years old; the group of from 35 to 50 years old; and the group of 51 years old or over belonging to the elderly or retirement investors. The study shows that there is no willingness to take risks among the 51-year-old-or-over investor group (the rate of investors willing to take risks over investors unwilling to take risks is 13/77). The rates of taking risks among remaining groups are as follows: $47 / 33$ for the group of less than 27 years old; 83/41 for the group of from 27 to 35 years old; 77/51 for the group of from 35 to 50 years old (Table 4).

Table 4. The bidirectional frequency statistic table for age

\begin{tabular}{|c|c|c|c|c|c|c|}
\hline & & \multicolumn{4}{|c|}{ age } & \multirow[b]{2}{*}{ Total } \\
\hline & & $\begin{array}{c}\text { under } 27 \text { years } \\
\text { old }\end{array}$ & $\begin{array}{c}\text { from } 27 \text { to } 35 \text { years } \\
\text { old }\end{array}$ & $\begin{array}{c}\text { from } 35 \text { to } 50 \text { years } \\
\text { old }\end{array}$ & $\begin{array}{c}\text { from51 years old or } \\
\text { more }\end{array}$ & \\
\hline \multirow[t]{2}{*}{ Risk } & unwilling to take risks & 33 & 41 & 51 & 77 & 202 \\
\hline & willing to take risks & 47 & 83 & 77 & 13 & 220 \\
\hline Total & & 80 & 124 & 128 & 90 & 422 \\
\hline
\end{tabular}

3.3 Inspecting the Relationship between the Number of Experience Years in the Stock Market and Taking Risks in Making Investment Decisions

Table 5. Chi-square test results for experience

\begin{tabular}{lcc}
\hline & Value & p-value \\
\hline Pearson Chi-Square & $59.994 \mathrm{a}$ & .000 \\
Cramer's V & .377 & .000 \\
Contingency Coefficient & .353 & .000 \\
\hline
\end{tabular}

The study indicates that there is the difference between the investors with different experience levels because of all p-values are less than 0.05. The objects are devided into following groups: the group of less than 2 years of experience; the group of from 2 to 5 years of experience and the group of more than 5 years of experience. Evaluating the rate of investors willing to take risks over investors unwilling to take risks proved that the group of more than 5 years of experience takes risks with the rate of 122/43; the rate for the group of less than 2 years of experience is 51/112; and the rate for the group of from 2 to 5 years of experience is 47/47, (Table 6). 
Table 6. The bidirectional frequency statistic table for stock investing experience

\begin{tabular}{llcccc}
\hline & & \multicolumn{3}{c}{ Exp } & \multirow{2}{*}{ Total } \\
\cline { 3 - 5 } & & under 2 years & from 2 to 5 years & more than 5 years & 202 \\
\hline \multirow{2}{*}{ Risk } & unwilling to take risks & 112 & 47 & 43 & 220 \\
& willing to take risks & 51 & 47 & 122 & 422 \\
\multirow{2}{*}{ Total } & & 163 & 94 & 165 & 422 \\
\hline
\end{tabular}

3.4 Inspecting the Relationship between the Educational Qualification and Taking Risks in Making Investment Decisions

Table 7. Chi-square test results for educational qualification

\begin{tabular}{lcc}
\hline & Value & p-value \\
\hline Pearson Chi-Square & $2.442 \mathrm{a}$ & .295 \\
Cramer's V & .076 & .295 \\
Contingency Coefficient & .076 & .295 \\
\hline
\end{tabular}

All p-values are larger than 0.05 illustrating that there is no difference in the willingness to take risks of investors with different educational qualification (the investors are devided into 3 groups: the investors with high-school education, the investors with university education and the investors with postgraduate education).

\subsection{Inspecting the Relationship between the Income Level and Taking Risks in Making Investment Decisions}

Table 8. Chi-square test results for income level

\begin{tabular}{lcc}
\hline & Value & p-value \\
\hline Pearson Chi-Square & $.334 \mathrm{a}$ & .846 \\
Cramer's V & .028 & .846 \\
Contingency Coefficient & .028 & .846 \\
\hline
\end{tabular}

The testing illustrated that investors with different income levels have the same investing psychology (imcome level is divided into following groups: the group with the income level of less than 5 million VND; the group with the income level of from 5 to 10 million VND and the group with the income level of higher than 10 million VND).

3.6 Inspecting the Relationship between the Marital Status and Taking Risks in Making Investment Decisions

Table 9. Chi-square test results for marital status

\begin{tabular}{lcc}
\hline & Value & p-value \\
\hline Pearson Chi-Square & $81.098 \mathrm{a}$ & .000 \\
Cramer's V & .438 & .000 \\
Contingency Coefficient & .401 & .000 \\
\hline
\end{tabular}

All p-values are less than 0.05 illustrating that there is difference in the investing psychology of the investors with different marital status. The investors includes 3 groups as follows: the group of single investors; the group of married investors; and the group of divorced investors. The testing results show that the single and divorced investor groups are prone to be much more willing to run risks (the rates of investors willing to take risks over investors unwilling to take risks of these two groups are 88/33 and 94/49 respectively), while the number for the married investor group is low of 38/120. (table 10). 
Table 10. The bidirectional frequency statistic table for marital status

\begin{tabular}{|c|c|c|c|c|c|}
\hline & & \multicolumn{3}{|c|}{ Status } & \multirow{2}{*}{ Total } \\
\hline & & single investor & married investors & divorced investors & \\
\hline \multirow{2}{*}{ risk } & unwilling to take risks & 33 & 120 & 49 & 202 \\
\hline & Total & 121 & 158 & 143 & 422 \\
\hline
\end{tabular}

The table shows that there is some difference among investors with different gender, age, investing experience and marital status in taking risks in trading stocks. The investors with different education qualification and income level have the same decision in taking risks in trading stocks.

3.7 Inspecting the Relationship between the Individual Investors in Hanoi and Ho Chi Minh Exchange and Taking Risks in Making Investment Decisions

Table 11. The Chi-Square test result for the stock exchange

Note. Results from SPSS.

\begin{tabular}{lcc}
\hline & Value & p-value \\
\hline Pearson Chi-Square & 4.596 & .032 \\
Cramer's V & -.104 & .032 \\
Contingency Coefficient & .104 & .032 \\
\hline
\end{tabular}

All p-value less than are less than 0.05 illustrating that there is difference in taking risks in making investment decisions between individual investors in Hanoi and Ho Chi Minh exchange. The testing results show that the rate of individual is willing to take risks in Ho Chi Minh City (121/211) is higher than in Hanoi (99/211) (Table 11).

Table 12. The dimentional frequence statistics for the stock exchange

\begin{tabular}{lcccc}
\hline & & \multicolumn{2}{c}{ Bezone } & \\
& & Ho Chi Minh city & Hanoi & Total \\
\hline \multirow{2}{*}{ Risk } & unwilling to take risks & 90 & 112 & 202 \\
& willing to take risks & 121 & 99 & 220 \\
Total & & 211 & 211 & 422 \\
\hline
\end{tabular}

Note. Result from SPSS.

The statistic results show that individuals in Hanoi exchange tend to be less unwilling to take risks than individuals in Ho Chi Minh City.

\section{Conclusion}

The study reveals that there is some differences among different groups of investors in Vietnam Stock Market. There is internal difference in 4 out of 6 studied groups of investors in taking risks in trading stocks. The gender, age, investment experience and marital status associate with the decision making of investors. The investors with different education qualification and income level have the same decision in taking risks in trading stocks.

Men are prone to be more willing to take risks than women in trading and this result is also proved by Barrer and Odean (2001); Wood and Zaichkowsky (2004) that men are often overconfident and trade with a larger volume than women. Lunderberg, Fox and Puncochar (1994) also illustrated that men are often more confident than women in trading stock. Although both men and women have the same understanding, the feeling often influences on men's decision making, (Prince, 1993), (Lunderberg, Fox, \& Puncochar, 1994). Besides, due to the characteristics of Vietnamese, women often play an important role in families' spending, so they have to consider carefully in trading stock to minimize the cost and to avoid risks and be unwilling to take risks.

The study also shows that the investors with different ages have different investing psychology, which is similar to the result of Riley and Chow (1992); Evan (2004); Lutfi (2010); Jain and Mandot (2012). The study proves that the investors with the age of from 27 to 50 are prone to be more willing to take risks than the investors with the age of over 50. It is clear that young investors are often more willing to take risks while the elder or retirement investors 
like to be safe in trading stocks. The elder or retirement investors always want to have an ease life with no pressure, therefore, they decide to invest safely.

The establishment of Hanoi exchange defines clearly the differences in taking risks of investment individual in Ho Chi Minh city and Hanoi exchanges. The investment individuals in Ho Chi Minh City are much more willing to take risks than individuals in Hanoi. The reason may be experience factors (to be discussed in the next section) in participating to regional markets which has affected to willingness to take risks in making investment decisions. This trend also explained that investors in Hanoi exchange have small investment and stock to avoid large risks which can affect personal finance.

The study brings out the association between the investment experience and investment decision making. The investors with the investment experience of over 5 years tend to be more willing to take risks while the investors with the investment experience of less than 5 years often make a safe decision in trading stocks. This result is new discovery for Vietnam Stock Market. This result also did not exist in other studies. The reason for this is that the investors with the investment experience of less than 5 years always want to participate to survey the market, and when they accumulate enough experience of from 5 years or more, they are proned to invest aggressively and to be willing to take risks because they can forecast the market movement.

In term of marital status, the study illustrates that married investors are less willing to take risks than the others because they have to consider their family issues. This is also similar to the conclusion of Barber and Odean (2001); Raganathan (2004); Lutfi (2010).

To sum up, demographical factors influence on the decision making of investors on Vietnam Stock Market. Women have to be responsible for their families' spending, so they often make the safe decision in trading stocks. The elderly or retirement investors are prone to be less willing to run risks in trading stocks due to the fact that they want to have an ease life when they are getting old. Moreover, the married investors are often less willing to take risks than the single or divorced investors. The psychological factor independent on family issues is the investment experience, which shows that the investors with the investment experience of over 5 years tend to be more willing to take risks than the others.

\section{Acknowledgments}

This work was supported in part by grants from the Innovation Program of Shanghai Municipal Education Commission (No. 13ZS065), the Shanghai Philosophy and Social Science Planning Project (No. 2012BGL006), and the National Social Science Foundation of China (No. 13CGL057).

\section{References}

Aczel. (2008). Business Statistics. McGraw-Hill.

Bajtelsmit, V. L., \& Bernasek, A. (1996). Why Do Women Invest Differently than Men? Financial Counseling and Planning, 1-10.

Bajtelsmit, V. L., \& VanDerhie, J. L. (1997). Risk Aversion and Pension Investment Choices. In M. S. Gordon, O. S. Mitchell \& M. M. Twinney (Eds.), Positioning Pensions for the Twenty-first Century. Philadelphia: University of Pennsylvania Press.

Bajtelsmit, V. L., Bernasek, A., \& Jianakopolos, N. A. (1996). Gender effects in pension investment allocation decisions (pp. 145-156). Working Paper: Center for Pension and Retirement Research.

Barber, B. M., \& Odean, T. (2001). Boys will be Boys: Gender, Overconfidence, and Common Stock Investment. The Quarterly Journal of Economics, 261-292. http://dx.doi.org/10.1162/003355301556400

Barber, B. M., Odean, T., \& Zhu, N. (2009). Do Retail Trades Move Markets? Review of Financial Studies, 22(1), 151-186. http://dx.doi.org/10.1093/rfs/hhn035

Evans, J. (2004). Wealthy Investor Attitudes, Expectations, and Behaviors toward Risk and Returns. Journal of Wealth Management, 12-18. http://dx.doi.org/10.3905/jwm.2004.412350

Fama, E. (1970). Efficient capital markets: are view of theory and empirical work. Journal of Fiance, 383-417. http://dx.doi.org/10.2307/2325486

Gervais, S., Heaton, J., \& Odean, T. (2002). The positive role of overconfidence and optimism in investment policy. UCBerkeley: Haas School of Business.

Glaser, M., \& Weber, M. (2007). Overconfidence and trading volume. Geneva Risk and Insurance Review, 32(1), 1-36. http://dx.doi.org/10.1007/s10713-007-0003-3 
Hinz, R. P., McCarthy, D. D., \& Turner, J. A. (1996). Are women more conservative investors? Gender differences in participant-directed pension investments. In M. S. Gordon, O. S. Mitchell \& M. M. Twinney (Eds.), Positioning pensions for the twenty-first century. Philadelphia: University of Pennsylvania Press. Retrieved from http://econpapers.repec.org/paper/woppennpr/96-17.htm

Jain, D., \& Mandot, N. (2012). Impact of Demographic Factors on Investment Decision of Investors in Rajasthan. Journal of Arts, Science \& Commerce, 2(3), 81-92. Retrieved from http://www.researchersworld.com/vol3/issue2/vol3_issue2_3/Paper_10.pdf

Kahneman, D., \& Tversky, A. (1979). Prospect Theory: An Analysis of Decision under Risk. Econometrica, 47(2), 263-291. http://dx.doi.org/10.2307/1914185

Kenney, J. F., \& Keeping, E. S. (1951). Mathematics of Statistics Hyperlink (2nd ed.). Retrieved from http://www.amazon.com/exec/obidos/ASIN/B0007HR7SY/ref=nosim/weisstein-20

Le, T. N. L. (2009). To study the bahaviuoural theory on Vietnam Stock Market. Thesis, Ho Chi Minh Economics University.

Lundeberg, M. A., Fox, P. W., \& Punccohar, J. (1994). A Critique of "Highly Confident but Wrong: Gender Differences and Similarities in Confidence Judgments. Journal of Educational Psychology, 114-121. http://dx.doi.org/10.1037/0022-0663.86.1.114

Lutfi. (2010). The Relationship Between Demographic Factors and Investment Decision in Surabaya. Journal of Economics, Business and Accountancy Ventura, 13(3), 213-224. Retrieved from http://idci.dikti.go.id/pdf/JURNAL/JournalofEconomicsBusinessAccountancyVentura/2010/VOL\%2013\%2 0NO\%203/13-52-1-PB.pdf

Nguyen, D. H. (2012). The investors' bahaviuor on Vietnam Stock Market. Thesis, Hanoi National Economics University.

Prince, M. (1993). Women, Men, and Money Styles. Journal of Economic Psychology, 175-182. http://dx.doi.org/10.1016/0167-4870(93)90045-M

Raganathan, K. (2004). A Study of Fund Selection Behavior of Individual Investors Towards Mutual Funds. Madurai Kamaraj University. Retrieved from http://www.scribd.com/doc/58891216/SSRN-id876874

Riley, W., \& Chow, K. V. (1992). Asset Allocation and Individual Risk Aversion. Financial Analysts Journal, 48(6), 32-37. http://dx.doi.org/10.2469/faj.v48.n6.32

Shefrin, H., \& Statman, M. (1985). The Disposition to Sell Winners Too Early and Ride Losers Too Long: Theory and Evidence. Journal of Finance, 40(3), 777-790. http://dx.doi.org/10.1111/j.1540-6261.1985.tb05002.x

Shiller, R. J. (2000). Measuring Bubble Expectations and Investor Confidence. The Journal of Psychology and Financial Markets, 1(1), 49-60. http://dx.doi.org/10.1207/S15327760JPFM0101_05

Wood, R., \& Zaichkowsky, J. L. (2004). Attitudes and trading behavior of stock market investors: a segmentation approach. Journal of Behavioral Finance, 5(3), 170-17. http://dx.doi.org/10.1207/s15427579jpfm0503_5

\section{Copyrights}

Copyright for this article is retained by the author(s), with first publication rights granted to the journal.

This is an open-access article distributed under the terms and conditions of the Creative Commons Attribution license (http://creativecommons.org/licenses/by/3.0/). 